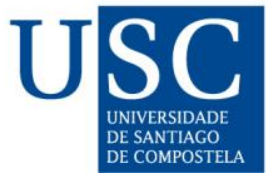

\title{
Epilobium brachycarpum C. Presl in Europe: forty years later
}

Jesús Izco

Department of Plant Biology, Santiago de Compostela University, E-15702, Santiago de Compostela, Spain. jesus.izco@usc.es

\section{Summary}

After Epilobium brachycarpum C. Presl was first cited in Madrid (Spain) in 1983, the species has multiplied and extended countrywide in the last 40 years. Subsequent new citations indicate its presence in other European countries in western part of the continent. Based on published information and new records from Spain, its expansion in the Iberian Peninsula and Europe in general is summarized.

Keywords: Aliens; invasive flora; globalisation; neophytes; xenophytes.

\section{Resumen}

Desde que Epilobium brachycarpum C. Presl se citó por primera vez en Madrid (España) en 1983, la especie se ha multiplicado y extendido a lo largo del país durante los últimos 40 años. Nuevas citas indican su presencia en otros países europeos en la parte occidental del continente. A partir de información publicada y nuevos registros en España, se resume su expansión en la Península y Europa en general.

Palabras clave: Exóticas; flora invasora; globalización; neófitos; xenófitos.

Recibido: 22/10/2020; Aceptado: 02/05/2021

\section{INTRODUCTION}

Epilobium brachycarpum C. Presl is an annual willowherb that reaches a height of up to $1.50 \mathrm{~m}$, highly ramified with alternating leaves, either linear or linear-elliptical, with open-paniculate inflorescence, short pedunculate fruits, either linear or linear-elliptic (Solomon, 1982; Nieto, 1997; Hoch, 2012). The species is native to North America and is present in states in central west areas of the USA, and provinces to the south of Canada, from British Columbia to Quebec (USDA, NRCS, 2019). Although its presence south of the US fronter has been occasionally rejected, it has been mentioned in several Mexican states: Durango, Guerrero, Mexico FD, Michoacán, Morelos, Puebla, Oaxaca and Tlaxcala (Munz, 1960; GBIF, 2020 a).

Its presence in Europe has been documented for 40 years with the first record in Madrid (Spain) (Izco, 1983), sub E. paniculatum Nutt. Many publications mentioned the presence of the species in 
the Iberian Peninsula, in Spain: Pujadas (1986); Rivas Martínez \& Cantó (1991), Gavilán et al. (1993), Mateo et al., (1996), Nieto (1997), Martín et al. (2000), Mateo \& Pisco (2002), Cardero et al. (2004), Gabriel et al. (2005), Oltra \& Conca (2006), Royo (2006), Sanz et al. (2006), Lázaro (2008), Blanca et al. (2009), Castro et al. (2009); Delgado \& Paz (2009), García Muñoz (2009), Romero (2009), Acedo (2011), Anonymous (2012), Aymerich (2012), López Tirado (2013), Vázquez \& Palacios (2013), Elvira et al. (2014), Lázaro (2012), López Tirado \& Jiménez (2014), Rodríguez García et al. (2014), Sánchez \& Otero (2014), Salvador (2015), Sánchez Gullón \& Verloove (2015), Asturnatura (2016), Márquez et al. (2016), Rodríguez Torres (2016), García Cardo (2018), Mateo (2018), Gestí \& Villar (2019), León \& Ascaso (2020); it has been also mentioned in Vizcaya (Anonymous, 2012), but it has not been possible to confirm this citation. In Portugal, it is present in the districts of Aveiro, Bragança, Castelo Branco, Guarda and Viseu, all of which lie north of this country (Almeida \& Freitas, 2012; Alves \& Aguiar, 2012; Marchante et al. 2014).

The first citation in the rest of the European continent is French (Magnanon, 1995), followed in France by other mentions: Provost (1998), Lamaison \& Deschatres (2003), Bardet et al. (2008), Bedouet (2009), Verloov \& Lambinon (2009), Madre \& Mayrand (2018). The distribution of E. brachycarpum in France in $10 \times 10 \mathrm{~km}$ grids, is available in INPN.MNHN (2015). The first citation in Germany appeared at the end of the 20th century, in Palatinate (Lang \& Wolff, 1991), followed by many others in different Landers: Lenker (2001), Jung (2002), Hand (2003), Bönsel \& Ottich (2005), Höcker \& Hetzel (2006), Emrich (2008), Gregor et al. (2013). Epilobium brachycarpum is also present in others European continental countries: Czech Republic (Salák \& Hadinec, 2017; Kaplan et al. 2018); Italy (Alessandrini, 2016; Alessandrini \& Ardenghi, 2018); Belgium (Remacle, 2014a, 2014b; Verloove et al. 2019). The species has also been identified in Great Britain: in Essex (Adams, 2010) and Suffolk (Sanford, 2016) (Fig. 2).

Records in South America of the presence of E. brachycarpum as alien can be found in Chile, province of Biobio (Macaya \& Faúndez, 1998), and in Argentina's provinces of Córdoba, Chubut, Neuquen and Río Negro (Flora Argentina, 2018). Given its unstoppable expansion, the species has even appeared in New Zealand (Handler, 2009).

Epilobium paniculatum Nutt. is a later synonym of E. brachycarpum C. Presl but has been frequently used for years. Accordingly, the proposal put forward by Hoch \& Raven (1981) of rejecting the name $E$. brachycarpum as nomen rejiciendum and maintaining E. paniculatum as a conserved name, was not accepted (Brummitt, 1984). The many specific synonyms of the taxon are listed in Epilobium brachycarpum C. Presl in GBIF (2020 b).

Forty years after E. brachycarpum's first quote in Europe, the article aims to show its expansion on this continent and the diversity of habitats it colonizes.

\section{MATERIAL AND METHODS}

The materials corresponding to the new localities in Spain are deposited in the SANT Herbarium. Only printed sources of information have been consulted. In addition to bibliographic quotations, other data have been analized from the Global Biodiversity Information Facility (GBIF, 2020 b) and the Biodiversity Foundation-Royal Botanical Garden of Madrid (ANTHOS, 2012). For the transposition of the presences of the species in Spain at the provincial level and in Portugal at 
the district level, Google maps has been used. In all cases, the entries Epilobium paniculatum Nutt., E. paniculatum Nutt. ex Torr. \& A Gay. y E. brachycarpum C. Presl have been analyzed. The Extend of Occurrence (E00) of Epilobium brachycarpum in the Iberian Peninsula has been done by taking the capitals of Spanish provinces and the capitals of Portuguese districts as polygon angles. Similarly, the calculation of EOO in Europe has been performed by taking the capitals of each country as polygon angles, except for France, where the western vertex has been positioned in La Rochelle to encompass, at least in part, the French populations on the Atlantic coast. To calculate the EOO in the Iberian Peninsula and the rest of Europe, Maps \& Directions (2018) has been employed.

\section{RESULTS}

The number of papers mentioning E. brachycarpum as a neophyte in Spain have grown decade after decade since its first indication in Madrid: 1980 (2), 1990 (4), 2000 (13) and 2010 (16). Portuguese publications are from the 2010s. The Spanish provinces and the Portuguese districts where the species have been mentioned can be seen in Figure 1. Written previous mentions of Epilobium brachycarpum indicate its presence in 25 Spanish continental provinces.

The new records correspond to the province of Guadalajara, in central Spain, and the provinces of Orense and Lugo in the extreme northwest of the Iberian Peninsula. In Guadalajara, the species is common in fallow areas and disturbed soils by the preparatory work for the expansion of the capital. In the province of Lugo, the species is distributed into two different areas: to the south by road $\mathrm{N}-120$, from the eastern border with Orense province to near Monforte de Lemos, following the River Sil Valley; to the north by road N-VI (Madrid-La Coruña) on both the southern slope of the Piedrafita del Cebreiro Pass (province of León) and the northern slope (province of Lugo). In the province of Orense, the species is present along the road N-120, from Carballeda de Valdeorras to Petín. In Orense and Lugo, it is present along roads and often around petrol stations. Soils have a limous or limo-clayey texture. Other new findings come from the provinces, where the species was already known, of Palencia, León and Zamora, and correspond to railway stations (Figure 1). 
Figure 1. Distribution of Eplobium brachycarpum in continental Spain (provinces) and Portugal (districts). 1: Previously web cited administrative entities. 2: Previously published cited administrative entities 3: Newly cited provinces

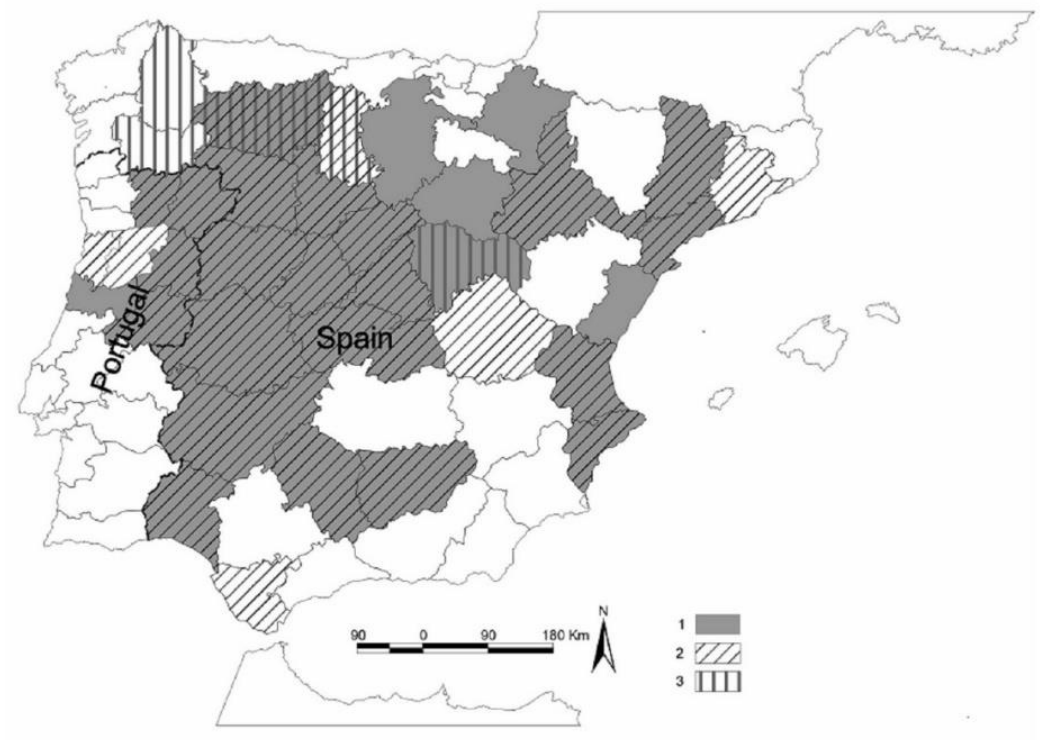

According to the models of Rivas-Martínez et al. (2004 a, b), the bioclimate viewpoint, the Guadalajara locality is subject to Supramediterranean thermotype climates, in the Biogeographic Mediterranean Region, Western Mediterranean Sub-Region, Mediterranean Central Iberian Province and Castilian Sub-Province. Those from the localities of Orense and south of Lugo are subject to Submediterranean bioclimates in the Biogeographic Eurosiberian Region, Atlantic European Sub-Region and Cantabroatlantic Province, while the citations from the Piedrafita of Cebreiro Pass are subject to Supratemperate Supramediterranean climates in the Biogreographic Eurosiberian Region, Atlantic European Sub-Region and Orocantabrian Province.

\section{DISCUSSION}

Information on the presence of E. brachycarpum in the Iberian Peninsula is expanded on the web. According to ANTHOS map (2020) it is present in the provinces of Avila, Badajoz, Cáceres, Castellón de la Plana, León, Lérida, Lugo, Madrid, Salamanca, Segovia, Tarragona, Valencia, Valladolid and Zaragoza. However, the point of Lugo province does not correspond to the associated information; on the contrary, the mentioned locality 'Campo' belongs to the Municipality of Ponferrada, province of León, with coordinates $42^{\circ} 32^{\prime} 15^{\prime \prime} \mathrm{N} 6^{\circ} 33^{\prime} 40^{\prime \prime} \mathrm{W}$. Also, from herbarium samples, GBIF (2020 b) indicates the presence of the species in numerous Spanish provinces: Alicante, Ávila, Badajoz, Burgos, Cáceres, Cantabria, Córdoba, Guadalajara, Huelva, Jaén, León, Lerida, Lugo, Madrid, Navarra, Palencia, Salamanca, Segovia, Soria, Toledo, Valencia, Valladolid, Zamora, Zaragoza. The point that indicates on the map the presence of the especies in the province of Lugo is also a typo, since the associated data also correspond to the locality of Campo (León), as in ANTHOS. It is the same for the point indicating the presence of the species in Cantabria, since the associated information states that the locality is Pozuelo de Alarcón (Madrid), with coordinates $40^{\circ} 26^{\prime} 27^{\prime \prime} \mathrm{N} 3^{\circ} 48^{\prime} 53^{\prime \prime} \mathrm{W}$. GBIF (loc. cit.) also indicates the presence of the species 
in the Portuguese districts of Bragança, Castelo Branco, Coimbra, Guarda and Viseu. These same Portuguese districts are also indicated in Araujo et al. (2019).

In the last forty years, the species has rapidly expanded in the Iberian Peninsula. Currently, in mainland Spain it is present in 34 provinces out of a total of 47, or 73\%, and in Portugal it is present in 4 continental districts over a total of 18 (22\%). The Iberian EOO has an approximate area of $c$. $450,000 \mathrm{~km}^{2}$ (Fig. 2).

Figure 2. Extent of Occurrence for Epilobium brachycarpum in the Iberian Peninsula A: Alicante. B: Barcelona. Ca: Cádiz. Co: Coimbra. Lu: Lugo. P: Pamplona. H: Huelva

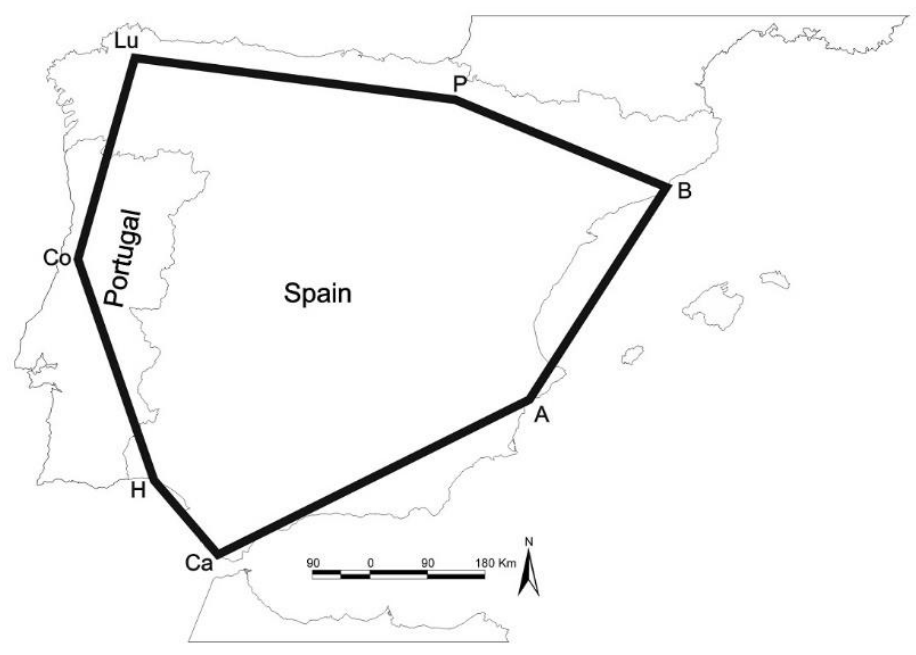

The global distribution of the panicled wilowherb in the Iberian Peninsula according to the proposal of Rivas-Martínez et al. (2004 a, b), extends across most of the Mediterranean Region, Western Mediterranean Subregion, in the chorological provinces Mediterranean West Iberian (Luso-Extremaduran and Carpetano-Leonese Sectors), Betican, Mediterranean Central Iberian (Castilian, Oroiberian and Low Aragonese Sectors), Balearic-Catalan-Provençal (ValencianCatalonian Sector); in the Eurosiberian Region, Atlanic-Central European Subregion in the chorological province Atlantic-European (Cantabro-Atlantic and Orocantabrian Provinces) and in the Alpine-Caucasian Subregion, Céveno-Pyrenean Province (Central-Pyrenean Sector). From a bioclimatic point of view, Epilobium bachycarpum in the Iberian Peninsula is present in the termotypes Thermomediterranean, Mesomediterranean, Supramediterranean, and Mesotemperate Submediterranean; as far as the ombrotypes are concerned, it is present in the Temperate oceanic Submediterranean and Mediterranean pluviseasonal oceanicones.

The wide distribution of Epilobium brachycarpum is determined by its annual condition, its dispersion either by air (anemochory) or adhering to different damp or wettened objects, or on rough surfaces of different vectors as trains and motor vehicles given their alignment by means of railway lines and roads; on other occasions, dispersion is linked to people or animals (zoochory) if we bear in mind its presence in agricultural settings. The species shows a long-distance dispersion 
of 1-several km/year (Gregor et al. 2013), that is longincua or in long-distance, sense Font Quer (1963). Its wide dispersion is also based by its wide ecological valence.

As Gregor et al. (2013) point out, the species shows great expansive potential in Europe favored by the genetic diversity of the populations, sourced from at least one triple introduction (Nierbauer et al. 2016). The European EOO -excluded the Iberian Peninsula- cover a surface area of $c .980,000$ $\mathrm{km}^{2}$ with the species being present in six countries; France, Germany, Belgium, Italy, the Czech Republic and Great Britain (see Fig. 3).

Figure 3. Extent of Occurrence for Epilobium brachycarpum in Europe, excluding the Iberian Peninsula

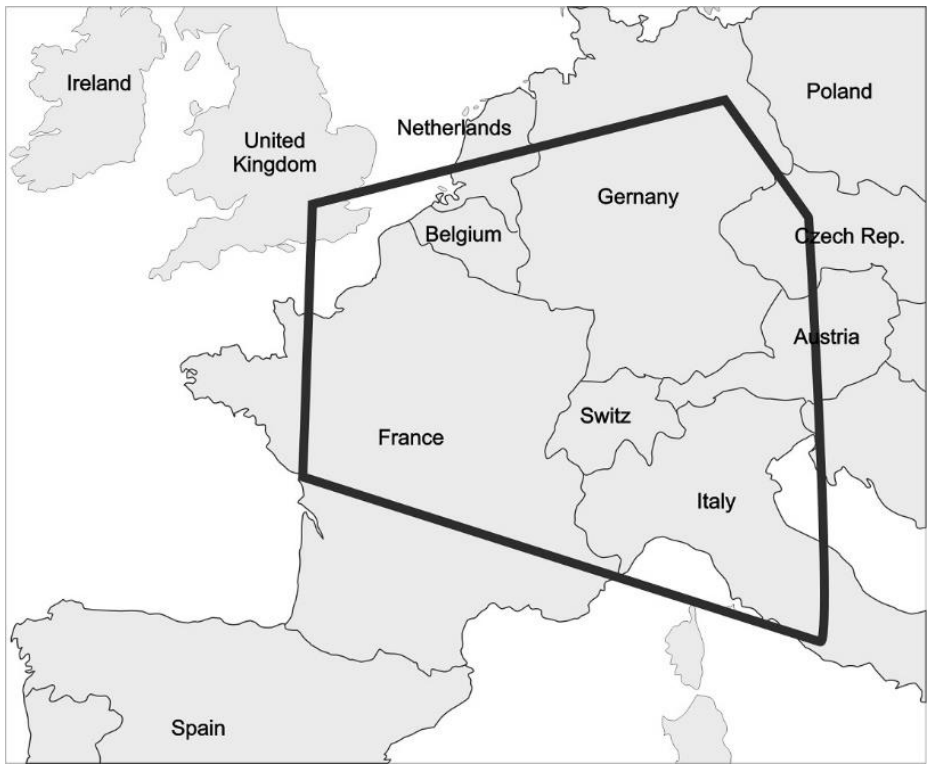

This species' ecology is broad in North America in wet environments of the USA (Moise et al. 2002; Riefner \& Boy, 2007; Hoch, 2019), also in Mexico (Munz, 1960), or in dry environments (Kaplan et al. 2018; Hoch, 2019). In the Iberian Peninsula, findings suggest seasonally wet environments, but they are clearly dry in general. In any case, Iberian populations probably have a different origin than other European populations - in rainy environments during the summer as their ecology differs because they occupy environments that face severe summer drought conditions (Alves \& Aguiar, 2012; Vazquez \& Palacios, 2013; López Tirado \& Jiménez Conejo, 2014). However, mentions being made to the presence of $E$. brachycarpun in wet environments are not lacking, such as banks of reservoires, lagoons and temporal watercourses (Anonymous, 2012; López Tirado \& Jiménez Conejo, 2014), even if they are subject to severe summer drought, which suggests certain humidity requirements of the species during the germination period.

According to López Tirado \& Jiménez Conejo (2014), currently in Spain the flora accompying this species is diverse: Dittrichia viscosa, Verbena officinalis, Daucus carota, Eryngium campestre, Heliotropium europaeum or Chrozophora tinctoria, plants that characterise classes like Artemisietea vulgaris, Onopordetea acanthi, Plantaginetea majoris or Stellarietea mediae, according 
to the phytosociological classification by Rivas-Martínez et al. (2002). In dry environments, the species comes with Chenopodium opulifolum, Conyza canadensis, Chondrilla juncea, Hirchsfeldia incana and Heliotropium europaeum as part of nitrophilous communities with summer and autumn optimum of the association Epilobio brachycarpi-Chenopodietum opulifolii Rivas-Martínez, Navarro et Cantó, the alliance Chenopodion muralis, the order Chenopodietalia muralis, and the class Stellarietea mediae (Rivas-Martínez et al. 2002). In other cases, it can be found on dry semi-natural meadow lands of the class Festuco-Brometea or on annual grasslands of the class TheroBrachypodietea (Anonymous, 2012).

In relation to its European extra-Iberian presence, the accompanying species of $E$. brachycarpum are Erigeron annuus, Picris hieracioides, Senecio inaequidans, Conyza canadensis, Daucus carota, Lotus tenuis, Tripleurospermum inodorum, Solidagpo canadensis, in a community belonging to Dauco-Melilotion (Weiss \& Gutte, 2007). According to Gregor et al. (2013), in Germany it is accompanied by Erigeron canadensis, Lactuca serriola, Tripleurospermum perforatum, Daucus carota, Taraxacum sect. Ruderalia and Aira spicaventi as part of the association Erigeronto canadensis-Lactucetum serriolae Lohmayer et Oberdorfer 1957, and the alliance Sisymbrion officinalis Tx. et al. in Tx. 1950, the order Sisymbrietalia J. Tx. in Lohmayer et al. 1968. Remacle (2014a) provides a long list of the flora that accompanies E. brachycarpum in the city of Treves (Germany), of which a large part is characteristic of the alliance Dauco carotae-Melilotion albi and the order Onopordetalia acanthi: Crepis foetida, Echium vulgare, Hypericum perforatum, Inula conyzae, Melilotus albus, Senecio inaequidens (http://www.omnibota.com/View/Flora_group.php?Type=2\&Groupe=69).

Generaly speaking, in Europe the species forms part of communities of different phytosociological classes: Stellarietea mediae, Artemisietea vulgaris, Molinio-Arrhenatheretea, Bidentetea tripartitae, Isoeto-Nanojuncetea and Polygono-Poetea annuae, mainly of the first.

\section{CONCLUSIONS}

Epilobium brachycarpum has been introduced to Europe repeatedly over the past forty years. Since these introductions it has expanded through the west of the continent, as has been documented by numerous collections referred to in numerous publications. From its previous behaviour his expansion in Europe is not over, always linked to anthropic environments. As far as mainland Spain and Portugal are concerned, there do not appear to be any limits to colonize the rainy strip of the northern peninsular or the southern territories with Mediterranean climate.

\section{Acknowledgments}

To F. Llamas for his information regarding the location of the town of Campo. To E. Alfaro by sending the information of Epilobium brachycarpum from LEB herbarium. To the reviewers of the article for their contributions. 


\section{References}

Acedo, A., Molina, A., Alonso, A. \& Llamas, F. (2011). 179. Novedades corológicas para la flora ibérica. Lagascalia, 31: 233-239.

Adams, K. (2010). Panicled Willowherb Epilobium paniculatum. New to the British Isles. Essex Naturalist, 27: 52-54. See Sanford, M. 2016.

Alessandrini, A. (2016). Flora degli ambienti ferroviari. Lo Scalo San Donato a Bologna. Quad Museo Civico Storia Nat Ferrara, 4: 37-44. [http://www.researchgate.net/publication/330194233].

Alessandrini, A. \& Ardenghi, N.M.G. (2018). Epilobium brachycarpum C. Presl (Onagraceae). In Galasso, G., Domina, G., Alessandrini, A. \& al. Notulae to the Italian alien vascular flora: 6. Ital Botanist, 6: 70.

[https://italianbotanist.pensoft.net/article/30560/download/pdf/].

Almeida, J.D. \& Freitas, H. (2012). Exotic flora of Portugal Continental. A new assessment. Bocconea, 24: 231237.

Alves, P. \& Aguiar, C. (2012). Três neófitos novos para a Flora de Portugal. Notas do Herbário Florestal do INIAV (LISFA): Fasc. XXXIV (2). Silva Lusitana, 20(1-2): 136-138.

Anonymous. (2012). Life Med Wet Rivers. Soc Pública Medio Ambiente Castilla León; Minist Agric Aliment Medio Ambiente; Grupo TRAGSA. [http://www.lifemedwetrivers.eu/sites/default/files/documentos/19 epilobium brachycarpum.p $\underline{\mathrm{df}]}$

ANTHOS (2012) Sistema de Información sobre las planas de España. [http://www.anthos.es/ Accessed IX.4.2020].

Araujo, P.V., Aguiar, C., Almeida, J.D., Porto, M., Holyoak, D. \& Clamote, F. (2019). Epilobium brachycarpum C. Presl - mapa de distribuição. Flora-On: Flora de Portugal Interactiva, Soc. Portuguesa Bot. [http://www.flora-on.pt/\#/Epilobium+brachycarpum].

Asturnatura. 2018. Epilobium brachycarpum C. Presl. Asturnatura.com [Online]. № 598. [https://www.asturnatura.com/especie/epilobium-brachycarpum.html].

Aymerich, P. (2012). Sobre algunes espècies al-lòctones a l'alt Segre (NE de la península Ibèrica), noves o molt rares per a la flora catalana. Orsis, 27: 195-207. [https://ddd.uab.cat/record/112328].

Bardet, 0., Fedoroff, E., Causse, G. \& Moret, J. (2008). Atlas de la flore sauvage de Bourgogne. Paris, Parthénope/Muséum Natl Hist. Nat.

Bedouet, F. (2009). Bienvenue chez les ch'tis ou la liste des principales espèces en extension récente dans le Nord-Pas de Calais ou présentes depuis peu aux portes de la region. Le Jouet du Vent, 21: 5. [https://www.cbnbl.org/sites/default/files/IMG/pdf/jouet 21-3.pdf].

Blanca, G., Cabezudo, B., Cueto, M., Fernández López, C. \& C. Morales, C. (Eds.). (2009). Flora Vascular de Andalucía Oriental, 4 vols. Consejería Medio Ambiente, Junta Andalucía, Sevilla.

Bönsel, D. \& Ottich, I. (2005). Über neue Funde des Kurzfrüchtigen Weidenröschens (Epilobium brachycarpum) in Frankfurt am Main. Bot Natur Hessen, 18: 43-54.

Brumiitt, R.K. (1984). Report of the committee for Spermatophyta: 27. Taxon, 33: 297-301. doi: $10.2307 / 1221174$

Cardero, S., Royo, F. \& Torres, L. (2004). Novetats florístiques per a les Terres de l'Ebre. B Inst Catalana Hist Nat, 72: 99-103.

Castro, V., Alonso, R. \& Llamas, F. (2009). De Plantis Legionensibus. Notula XXV. Lagascalia, 29: 322-329. 
Delgado, M.C. \& Paz, E. (2009). El jardín de la azucarera 'Santa Elvira', León (España). Bouteloua, 6: 7-9.

Elvira, R., Izuzquiza, A., Porras, I. \& Zaballos, J.P. (2014). Contribución al conocimiento de la flora alóctona del Real Jardín Botánico Juan Carlos I (Alcalá de Henares, Madrid). BV news Public Cient, 3(39): 1539.

Emrich, P. (2008). Epilobium brachycarpum C. Presl (Kurzfrüchtiges Weidenröschen) in Mittelhessen. Hess $\begin{array}{llll}\text { Flor } & \text { Briefe, } & 56(4): 59 \text { http://www.botanik- }\end{array}$ hessen.de/Pflanzenwelt/familien/onagra/epilobium/epil-bra.html].

Flora Argentina. (2018). Epilobium brachycarpum $\quad$ C. [://www.darwin.edu.ar/Proyectos/FloraArgentina/DetalleEspecie.asp?

$[\underline{w} w w \cdot$ forma $=\& v a r i e d a d=\&$ subespecie $=\&$ especie $=$ brachycarpum \&genero=Epilobium \&espcod=16 99].

Font Quer, P. (1963). Diccionario de Botánica. Edit. Labor. Barcelona. 1244 p.

Gabriel y Galán, J.M. \& Puelles, M. (2005). Notas corológicas sobre algunas plantas de Madrid. Biocien, 3: 317.

[http://revistas.uax.es/index.php/biociencia/article/download/640/596].

García Cardo, O. (2018). Aportaciones a la flora de la provincia de Cuenca, VI. Flora Montiberica, 71: 9-17. Edic. digital: 1988-799X 9.

García-Muñoz, B. (2009). Algunas novedades para las floras de Ávila y Cáceres. Bot Complutensis, 33: 5359.

Gavilán, R., Echevarría, J.E. \& Casas, I. (1993). Catálogo de la flora vascular de la Ciudad Universitaria de Madrid (España). Bot. Complut. 18: 175-201.

GBIF. (2020 a). Epilobium $\quad$ brachycarpum $\quad$ C.

[https://www.gbif.org/occurrence/search?country=MX\&taxon key=3189073].

GBIF. (2020 b). Epilobium brachycarpum C. Presl. [https://www.gbif.org/species/3189073].

Gestí, J., Vilar, L. (2019). Aportacions al coneixement de la flora de les Guilleries orientals i àrees properes (nord-est de Catalunya). Butll Insti Catalana 'Hist Nat, 83: 195-198. [http://revistes.iec.cat/index.php/BICHN/article/view/146793/145313]

Gregor, T., Bönsel, D., Starke-Ottich, I., Tackeckenberg, O., Wittig, R. \& Zizka, R. (2013). Epilobium brachycarpum: a fast-spreading neophyte in Germany. Tüxenia, 33: 259-283.

Hand, R. (2003). Neues aus der Flora der Region Trier: bemerkenswerte Funde von Samenpflanzen (Spermatophyta) im Berichtsjahr 2002. Dendrocopos, 30: 153-167.

Handler, B.J. (2009). The effects of disturbance and deer herbivory on plant invasions. Thesis, School of Biological Sciences, University of Canterbury, Canterbury: VII + 119 pp. See Gregor et al. 2013.

Hoch, P.C. (2012). Epilobium brachycarpum. In Jepson (Ed.) Jepson eFlora. [https://ucjeps.berkeley.edu/eflora/eflora display.php?tid=24341].

Hoch, P.C. \& Raven, P.H. (1981). Proposal to reject the name Epilobium brachycarpum Presl (1831) (Onagraceae). Taxon, 30: 666.

Höcher, R. \& Hetzel, G. (2006). Epilobium brachycarpum C. Presl, das Kurzfrüchtige Weidenröschen. Bayern. Flor. Rundbr. 40: 115-130. See: Verloove \& Lambinon, 2009.

INP-MNHN. (2015). Données d'observation flore du réseau des Conservatoires botaniques nationaux issues du système d'information de la FCBN [1500-2015]. [https://inpn.mnhn.fr/espece/cd nom/96143]. Izco, J. (1983). Epilobium paniculatum, nueva adventicia para Europa. Candollea, 38: 309-3015. 
Jung, K.D. (2002). Neuere bemerkenswerte Funde aus der Flora des Darmstädter Raumes 13. Folge Hess $\begin{array}{llll}\text { Florist } & \text { Briefe } & \text { 11-17. } & \text { http://www.botanik- }\end{array}$ hessen.de/Pflanzenwelt/familien/onagra/epilobium/epil-bra.html].

Kaplan, Z., Danihelka, J., Prančl, J.M., Ducháček, M., Ekrt, L., Kirschner, J., Brabec, J., Zázvorka, J., Trávniček, B., Dřevojan, P., Šumberová, K., Kocián, P., Wild, J. \& Petřik, P. (2018). Distributions of vascular plants in the Czech Republic. Part 7. Preslia, 90: 425-531. [http://www.preslia.cz/P184Kaplan2.pdf].

Lamaison, J.L. \& Deschâtres, R. (2003). Apparition en Auvergne d'Epilobium brachycarpum C. Presl = Epilobium paniculatum Nutt. ex Torr. \& A. Gray. Monde Plantes, 478: 19-20.

Lang, W. \& Wolff, P. (1991): Flora der Pfalz - Verbreitungsatlas der Farn- und Blütenpflanzen für die Pfalz und ihre Randgebiete. - Speyer. See Staud, A. (2003).

Lázaro, J.A. (2008). Nuevas citas para la flora vallisoletana, IV. Acta Bot Malacit, 33: 334-338.

Lázaro, J.A. (2012). Contribución al conocimiento de la flora alóctona abulense (Ávila, España). Fl. Montiber. 51: 3-6.

Lenker, K.-H. (2001). Epilobium brachycarpum Presl in Südhessen. Umweltamt Wissenschafts Darmstadt, Schriften, 16(4): 27-28. [https://www.delattinia.de/node/796].

León, J.L. \& Ascaso, J. (2020). Epilobium brachycarpum C. Presl y Oenothera rosea L’Hérit. Dos nuevas onagráceas para la provincia de Huesca (España). Flora Montiberica, 76: 133-134.

López-Tirado, J. \& Jiménez Conejo, A.M. (2014). 077.- Epilobium brachycarpum C. Presl. Folia Bot Extremadur, 8: 72-73.

López-Tirado, J., Muñoz, J.M. \& Hidalgo, P.J. (2013). Aportaciones a la flora vascular de la provincia de Córdoba I (Andalucía, España). Lagascalia, 33: 314-324.

Macaya, J., Faúndez, L. (1998). Boisduvalia glabella (Nutt.) Walp. y Epilobium brachycarpum C. Presl, dos especies nuevas de Onagraceae para Chile. Chloris Chilensis, 1. [http://chlorischile.cl].

Madre, F. \& Mayrand, F. (2018). Le wildroof: vers une végétation spontanée des toitures? Rencontre Toitures végétalisées et biodiversité. Agence Rég Biodiv Ile France. [http://www.arbidf.fr/sites/arb-idf/files/document/article/9_madre_mayrand_topager_0.pdf].

Magnanon, S. (1995). Grandes raretés armoricaines: redécouvertes et nouveautés. Erica, 6: 61-66. [http://www.cbnbrest.fr/site/pdf/erica/Erica_6_23047.pdf].

Maps \& Directions. (2018). Maps and Directions. [www.mapsdirections.info].

Marchante, H., Morais, M., Freitas, H. \& Marchante, E. (2014). Guia prático para a identificação de plantas invasoras em Portugal. Imprensa Univ Coimbra. 210 p. [https://www.researchgate.net/...Guia_Pratico_para_a_Identificacao_de_Plantas_Invasoras].

Márquez, F., García, D. \& Vázquez, F.M. (2016) Aportación al catálogo florístico de las Sierras de Tentudía y Aguafría (Badajoz, España). Fol. Bot Extremadur, 9: 25-47.

Martín Marcos, M.A., Sánchez Rodríguez, J.A. \& Elías Rivas, M.J. (2000). Aportaciones a la flora de Salamanca y Zamora (España). Lazaroa 21: 155-157.

Mateo, G. (2018). De flora valentina XVII. Flora Montiberica, 72: 112-115.

Mateo, G., Martínez, A., Bueno, L.M. \& Carreras, J.M. (1996). Aportaciones a la flora cesaraugustana, III. Flora Montiberica, 4: 38-43. [http://www.floramontiberica.org/FM/Flora_Monti04.pdf].

Mateo, G. \& Pisco, J.M. (2002). Aportaciones a la flora cesaragustana, XI. Flora Montiberica, 22: 18-22. [http://www.floramontiberica.org/FM/Flora_Monti21.pdf]. 
Moise, G.W. \& Hendrickson, B. (2002). Riparian vegetation of the san Joaquin river. Depart Water Resour, San Joaquin District. California.

[https://water.ca.gov/LegacyFiles/pubs/environment/riparian_vegetation_of_the_san_joaquin_river/rip_ veg_sjr.pdf].

Munz, P.A. (1960). North American Species of Epilobium South of the United States. Aliso: J Syst Evol Bot 4(3):

485-490. [https://scholarship.claremont.edu/cgi/viewcontent.cgi?referer=https://www.google.com/\&http sredir $=1 \&$ article $=1832 \&$ context=aliso].

Nierbauer, K.U., Juraj, P. \& Georg, Z. (2016). Invasive tall annual willowherb (Epilobium brachycarpum C. Presl) in Central Europe originates from high mountain areas of western North America. Biol Invasions, $\quad$ 18(11): 3265-3275. [https://www.researchgate.net/publication/304917418_Invasive_tall_annual_willowherb_Epilobi um_brachycarpum_C_Presl_in_Central_Europe_originates_from_high_mountain_areas_of_western North_America.]

Nieto, G. (1996). Notes on Epilobium (Onagraceae) from the western Mediterranean. An Jard Bot Madrid, 54: 255-264.

Nieto, G. (1997). Epilobium L. In: Castroviejo, S.; Aedo, C.; Benedí, C.; Laínz, M.; Muñoz Garmendia, F.; Nieto, G.; Paiva, J.; (Eds.) Flora iberica 8: 101-131.

Oltra, J.E. \& Conca, A. (2006). Aportacions a la flora de lnegre8.pdfa comarca de la Vall d'Albaida (província de València). Toll Negre, 8: 13-20. [http://www.internatura.org/grupos/apna/toll_negre8.pdf].

Provost, M. (1998). Flore vasculaire de Basse-Normadie. CD ROM (flor + atlas). Caen: Press Univ Caen. [http://www.cbnbrest.fr/atlas14/?numcbnb=7373].

Remacle, A. (2014a). Epilobium brachycarpum (Onagraceae) et Chondrilla juncea (Asteraceae), néophytes établis à Arlon (province de Luxembourg, Belgique). Dumortiera, 105: 9-12. [http://www.br.fgov.be/DUMORTIERA/DUM_105/Dum_105_9-

12_Epilobium_Chondrilla_Remacle.pdf].

Remacle, A. (2014b). Flore et végétation de la gare de triage à Arlon (Belgique). Natura Mosana, n.s. 67(2): $1-24$.

Riefner, R.E. \& Boy, S. (2007). New records of wetland and riparian plants in Southern California, with recommendations and additions to the national list of plant species that occur in wetlands. J Bot Res $\begin{array}{lll}\text { Inst } & \text { Texas, } & \text { 719-740. }\end{array}$ [https://www.jstor.org/stable/41971471?seq=1\#page_scan_tab_contents].

Rivas-Martínez, S. \& Cantó, P. (1991). Exsiccata Rivasgodayana I. Herbarium Universitatis Complutensis Phacultatis Pharmaciae (MAF). Rivasgodaya 6: 157-186.

Rivas-Martínez, S., Díaz, T.E., Fernández-González, F., Izco, J., Loidi, J., Lousã, M., Penas, A. (2002). Vascular plant communities of Spain and Portugal. Addenda to the syntaxonomical checklist of 2001. Itinera Geobot, 15(1): 5-432.

Rivas-Martínez, S., Penas, A. \& Díaz, T.E. (2004a). Bioclimatic map of Europe, 1:16,000,000. Geogr Service Univ. León, Spain. [http://www.globalbioclimatics.org/form/bi_med.htm].

Rivas-Martínez, S., Penas, A. \& Díaz, T.E. (2004b). Biogeographic map of Europe, 1:16,000,000. Geogr Service Univ. León, Spain. [http://www.globalbioclimatics.org/form/bg_med.htm]. 
Rodríguez García, A., Alfara, E., Alonso, R., García González, M.E. (2014). Aportaciones a la flora de las zonas húmedas de la provincia de Palencia. Flora Montiberica, 56: 29-46.

Rodríguez Torres, A. (2016). Flora y vegetación del norte de la provincia de Toledo (Valles del Alberche y Alto Tietar). Doctoral Thesis. Depart Ci Ambiental. Fac Ci Ambientales Bioquímica. 305 p. (manuscript).

[https://ruidera.uclm.es/xmlui/bitstream/handle/.../TESIS\%20Rodríguez\%20Torres.pdf?].

Romero, A.T. (2009). Onagraceae. In: Blanca, G., Cabezudo, B., Cueto, M., Fernández López, C. \& Morales, C. (Eds.). Flora Vascular de Andalucía Oriental 3: 241-247. Consejería Medio Ambiente, Junta Andalucía, Sevilla.

Royo, F. (2006). Flora i vegetació de les planes i serres compreses entre el riu Ebro i la serra d’Irta. Doctoral Thesis. Depart Biol Veg, Univ Barcelona. (manuscript). [file:///C:/Users/user/Downloads/02.FRP_PART_II.pdf].

Salàk, P. \& Hadinec, J. (2017). Epilobium brachycarpum C. Presl. In: Hadinec, J. \& Lustyk, P. (Eds.). Additamenta ad floram Reipublicae Bohemicae. XV. Zpr Čes Bot Společ, 44: 42-44.

Salvador, V. (2015). Diagnóstico de las especies invasoras dentro del ámbito del proyecto LIFE11 NAT ES/699. Soc Pública Infraestructuras Medio Ambiente Castilla León. [http://www.lifemedwetrivers.eu/sites/default/files/documentos/19_epilobium_brachycarpum.p df]

Sánchez García, I. \& Otero, A. (2014). Dos nuevas especies de Epilobium L. (Onagraceae) para Cádiz. Rev Soc Gaditana Hist Nat, 8: 43-46.

Sánchez Gullón, E. \& Verloove, F. (2015). New records of interesting xenophytes in the Iberian Peninsula, V. Lazaroa, 36: 43-50.

Sanford, M. (2016). Some recent Suffolk plant records. Trans. Suffolk Nat Soc, 52: 61-77. [https://issuu.com/suffolknaturalistssociety/docs/tsns52j].

Sánz, M., Dana, E.D. \& Sobrino, E. (2006). Aportaciones a la flora de la provincia de Segovia (España) III. Bot. Complutensis, 30: 105-111.

Solomon, J.C. (1982). The systematics and evolution of Epilobium (Onagraceae) in South America. Ann Missouri Bot Gard, 69: 239-335.

Staud, A. (2003). Massenbestand von Epilobium brachycarpum C. Presl auf der Bergehalde der Grube Maybach. Delattinia, Naturforschende Gesellschaft des Saarlandes. [https://www.delattinia.de/node/796].

USDA, NRCS. (2019). The PLANTS Database (http://plants.usda.gov). Epilobium brachycarpum. National Plant Data Team, Greensboro, NC 27401-4901 USA. [https://plants.sc.egov.usda.gov/java/].

Vázquez, F.M. \& Palacios, M.J. (2013). 064: Epilobium brachycarpum C. Presl. Folia Bot Extremadur, 7: 61.

Verloove, F., Groom, Q., Brosens, D., Desmet, P. \& Reyserhove, L. (2019). Manual of the Alien Plants of Belgium. Version 1.8. Botanic Garden Meise. Checklist dataset https://doi.org/10.15468/wtda1m accessed via GBIF.org on 2019-04-26. [https://www.gbif.org/species/141266538]

Verloove, F. \& Lambinon, J. (2009). Epilobium brachycarpum (Onagraceae), xénophyte américaine naturalisée dans le département du Nord (France). Dumortiera, 96: 17-19.

Weiss, V \& Gutte, P. (2007). Epilobium brachycarpum C. Presl, Kurzfrüchtiges Weidenröschen, eine neue Art in Mitteldeutschland. Sachisische Floristische Mitteilungen, 19: 118-125. 